Jurnal Keperawatan Silampari

Volume 5, Nomor 1, Desember 2021

e-ISSN: 2581-1975

p-ISSN: 2597-7482

DOI: https://doi.org/10.31539/jks.v5i1.2265

IDMEKp:

\title{
PERAN DUKUNGAN SUAMI DAN FAKTOR LAINNYA TERHADAP PEMANFAATAN PELAYANAN GIZI OLEH IBU HAMIL DENGAN RISIKO KURANG ENERGI KRONIS (KEK)
}

\author{
Fauzul Hayat ${ }^{1}$, Nurce Arifiati ${ }^{2}$, Tria Astika Endah Permatasari ${ }^{3}$ \\ Universitas Faletehan Serang ${ }^{1,2}$ \\ Universitas Muhammadiyah Jakarta ${ }^{3}$ \\ tria.astika@umj.ac.id ${ }^{3}$
}

\begin{abstract}
ABSTRAK
Penelitian ini bertujuan untuk mengetahui faktor penyebab perilaku pemanfaatan pelayanan gizi oleh ibu hamil dengan risiko KEK di Klinik Gizi Puskesmas Kasemen, Kota Serang. Metode penelitian ini menggunakan penelitian cross sectional. Hasil penelitian menunjukkan bahwa terdapat $66,2 \%$ ibu hamil yang dengan risiko KESK tidak memanfaatkan pelayanan gizi di klinik gizi. Perilaku pemanfaatan pelayanan gizi pada ibu hamil dengan risiko KEK paling dominan dipengaruhi oleh dukungan $(\mathrm{OR}=6,31 ; 95 \% \mathrm{CI}: 2,633-15,138)$. Selain itu perilaku ini dipengaruhi faktor lainnya yaitu kebutuhan (need) $(\mathrm{OR}=5,22 ; 95 \% \mathrm{CI}$ : $1,608-16,926)$ dan pendapatan keluarga $(\mathrm{OR}=2,48 ; 95 \% \mathrm{CI}: 1,061-5,814)$. Simpulan, ibu hamil dengan risiko KEK yang tidak memperoleh dukungan suami berisiko sebanyak 6,31 kali lebih berisiko untuk tidak memanfaatkan pelayanan gizi dibandingkan ibu hamil dengan risiko KEK yang memeroleh dukungan suami.
\end{abstract}

Kata Kunci: Ibu Hamil, Pelayanan Gizi, Risiko Kekurangan Energi Kronis (KEK)

\section{ABSTRACT}

This study aims to determine the factors that cause the behavior of using nutrition services by pregnant women with the risk of KEK at the Nutrition Clinic of the Kasemen Health Center, Serang City. This research method uses cross-sectional research. The results showed that $66.2 \%$ of pregnant women at risk of KESK did not take advantage of nutrition services at the nutrition clinic. The behavior of the utilization of nutrition services in pregnant women with the risk of SEZ was most dominantly influenced by support (OR=6.31; 95\% CI: 2.633-15.138). In addition, this behavior is influenced by other factors, namely needs $(O R=5.22 ; 95 \%$ CI: 1.608-16.926) and family income (OR = 2.48; 95\% CI: 1.061-5.814). In conclusion, pregnant women at risk of CED who do not receive support from their husbands are at risk of 6.31 times more at risk of not using nutrition services than pregnant women with the risk of CED who receive their husband's support.

Keywords: Pregnant Women, Nutrition Services, Risk of Chronic Energy Deficiency (KEK) 


\section{PENDAHULUAN}

Ibu hamil dengan masalah gizi dan kesehatan berdampak terhadap kesehatan dan keselamatan ibu dan bayi serta kualitas bayi yang dilahirkan (Griffiths et al., 2020). Kekurangan Energi Kronik (KEK) merupakan masalah gizi yang disebabkan karena kekurangan asupan makanan dalam waktu yang cukup lama (Depkes RI, 2015). Berdasarkan Pemantauan Status Gizi (PSG) tahun 2016, gambaran asupan makanan ibu hamil di Indonesia masih memprihatinkan, dimana proporsi ibu hamil dengan tingkat kecukupan energi (<70\%) Angka Kecukupan Energi (AKE) sekira 53,9\%, yang artinya lebih dari separuh ibu hamil di Indonesia mengalami kekurangan energi. Sementara proporsi ibu hamil dengan tingkat kecukupan protein ( $<80 \%)$ Angka Kecukupan Protein (AKP) sebesar 51,9\%, yang berarti separuh ibu hamil di Indonesia mengalami defisit protein (Kemenkes RI, 2018). Laporan data Riset Kesehatan Dasar (Riskesdas) tahun 2018, menunjukkan prevalensi ibu hamil KEK di Provinsi Banten sebesar 18,6\% lebih tinggi dari angka nasional sebesar 17,3\% (Kemenkes RI, 2019). Prevalensi KEK Kota Serang sebesar 30,77\% (Kemenkes R1, 2019). Adapun salah satu kasus KEK pada ibu hamil tertinggi di wilayah kerja Puskesmas Kasemen sebanyak 139 ibu hamil berdasarkan laporan pendataan program kesehatan ibu dan anak Puskesmas Kasemen bulan Desember tahun 2018 (Puskesmas Kasemen, 2019).

Kondisi ibu hamil KEK berisiko terjadinya kematian janin (keguguran), prematur, lahir cacat, Bayi Berat Lahir Rendah (BBLR) bahkan kematian bayi. Ibu hamil dengan risiko KEK dapat mengganggu tumbuh kembang janin yaitu pertumbuhan fisik (stunting), otak dan metabolisme yang menyebabkan penyakit menular di usia dewasa (Kemenkes RI, 2018). Berdasarkan laporan Dinas Kesehatan Kota Serang tahun 2018, angka kasus stunting sebanyak 2.543 anak (Pemkot Serang, 2020). Oleh karena itu, berbagai upaya yang dilakukan untuk meningkatkan pengetahuan ibu mengenai gizi yang dilakukan sejak periode kehamilan dapat mencegah terjadinya berbagai masalah gizi pada saat balita terutama stunting (Permatasari et al., 2021). Pada periode kehamilan juga intensi atau niat ibu untuk memberikan ASI ekslusif telah terbentuk, yaitu pemberian hanya ASI segera setelah bayi lahir hingga usia 6 (enam) bulan sangat direkomendasikan sebagai sumber makanan ideal bagi bayi yang dapat memenuhi kebutuhan gizi pada awal kehidupan bayi dan dapat mencegah terjadinya stunting (Permatasari \& Sudiartini, 2020; Permatasari et al., 2020; Permatasari et al., 2018)

Tingginya kasus risiko KEK pada ibu hamil dan kasus stunting di Kota Serang terutama di wilayah kerja Puskesmas Kasemen diperlukan upaya terobosan, salah satunya melalui upaya perbaikan dan peningkatan pelayanan gizi. Upaya pemerintah daerah untuk mengatasi masalah gizi dan peningkatan pelayanan gizi di masyarakat yaitu melalui program Pojok Gizi (POZI) di puskesmas. Program ini yaitu pelayanan gizi diberikan kepada setiap pengunjung puskesmas yang membutuhkan, baik yang datang secara spontan maupun yang datang atas rujukan dari unit pelayanan kesehatan lainnya baik puskesmas itu sendiri, puskesmas pembantu, polindes, posyandu atau rujukan dari Kepala Desa, Lurah ataupun masyarakat, bertujuan untuk pencegahan, penanggulangan, penyembuhan dan pemulihan penyakit yang berkaitan dengan gizi. Penelitian yang dilakukan terhadap balita berusia 6-24 bulan di Puskesmas Sawah Lega, Bandung Jawa Barat menunjukkan bahwa intervensi Pojok Gizi secara signifikan dapat meningkatkan status gizi balita sebagai upaya mencegah stunting (Ariani et al., 2020).

Ibu hamil dengan risiko KEK merupakan kelompok prioritas yang memerlukan pelayanan kesehatan dan informasi tentang masalah kesehatan dan gizi yang dihadapinya. Pemanfaatan pelayanan kesehatan merupakan hasil dari proses pencarian 
pelayanan kesehatan oleh sesorang atau kelompok (Padila et al., 2018). Berbagai studi sebelumnya menunjukkan bahwa pemanfaatan pelayanan kesehatan dipengaruhi oleh berbagai faktor (Ali et al., 2018). Pemanfaatan pelayanan kesehatan pada ibu hamil berdasarkan kerangka konseptual dari Model Perilaku yang dikembangkan oleh Anderson dipengaruhi oleh berbagai faktor yaitu mencakup: 1) predisposing factors (faktor predisposisi) predisposisi seperti karakteristik sosiodemografi ibu hamil, pengetahuan, sikap, nilai, budaya, persepsi dan faktor internal lainnya; 2) enabling factors (faktor pemungkin) seperti keterjangkauan terhadap pelayanan kesehatan dan keterpaparan informasi; dan 3) need factors (faktor kebutuhan) yaitu seperti faktor kesehatan reproduksi (Neupane et al., 2020; Tadesse, 2020; Akowuah et al., 2018).

Penelitian tentang faktor yang mempengaruhi pemanfaatan pelayanan gizi oleh ibu hamil dengan risiko kurang energi kronis sudah pernah dilakukan, namun fokus pada penelitian iin adalah mengetahui peran dukungan suami dan beberapa faktor lainnya terhadap pelayanan gizi oleh ibu hamil dengan risiko KEK.

\section{METODE PENELITIAN}

Desain penelitian ini menggunakan studi cross sectional. Penelitian ini dilaksanakan di wilayah Kerja Puskesmas Kasemen, Kota Serang. Pengumpulan data pada penelitian ini dilakukan pada bulan Februari-Juni 2019. Teknik pengambilan sampel penelitian ini yaitu total sampling. Populasi dalam penelitian adalah seluruh ibu hamil dengan risiko KEK di wilayah Puskesmas Kasemen Kota Serang. Sampel yang diambil merupakan total populasi sebanyak 139 orang berdasarkan hasil laporan pendataan program kesehatan ibu dan anak pada bulan Desember tahun 2018.

Variabel independen dalam penelitian ini adalah karakteristik ibu hamil dengan risiko KEK, pengetahuan, sikap, dukungan suami, jarak pelayanan kesehatan, pendapatan keluarga dan faktor kebutuhan (need). Variabel dependen dalam penelitian ini adalah perilaku pemanfaatan pelayanan kesehatan gizi. Data primer didapatkan dengan melakukan wawancara dengan ibu hamil dengan risiko KEK menggunakan kuesioner terstruktur yang telah dilakukan uji validitas dan reliabilitas. Analisis data dilakukan adalah analisis univariat, analisis bivariat menggunakan chi square, dan analisis multivariat menggunakan regresi logistik ganda dengan model prediksi.

\section{HASIL PENELITIAN}

Tabel. 1

Karakteristik Responden

\begin{tabular}{lcc}
\hline \multicolumn{1}{c}{ Karakteristik } & $\mathrm{n}$ & $(\%)$ \\
\hline Umur & & \\
$\leq 20$ tahun & 15 & 10,8 \\
$>20$ tahun & 124 & 89,2 \\
\hline Paritas & & \\
Primipara & 93 & 66,9 \\
Multipara & 42 & 30,2 \\
Granmultipara & 4 & 2,9 \\
\hline Pekerjaan & & \\
Tidak bekerja & 100 & 71,9 \\
Bekerja & 39 & 28,1 \\
\hline Pendidikan & & \\
Rendah & 70 & 50,4 \\
Tinggi & 69 & 49,6 \\
\hline
\end{tabular}




\begin{tabular}{lll}
\hline Pengetahuan & & \\
$\quad$ Rendah & 79 & 54,0 \\
$\quad$ Baik & 64 & 46,0 \\
\hline Sikap & & \\
$\quad$ Negatif & 93 & 66,9 \\
$\quad$ Positif & 46 & 33,1 \\
\hline Pendapatan keluarga & & \\
$\quad \leq$ UMR (Rp.3.827.000) & 76 & 54,7 \\
$\quad$ UMMR (Rp.3.827.000) & 63 & 45,3 \\
\hline Jarak pelayanan kesehatan & & \\
Jauh ( $\geq 5$ km) & 69 & 49,6 \\
Dekat (<5 km) & 70 & 50,4 \\
\hline Dukungan suami & & \\
$\quad$ Ya & 73 & 52,5 \\
$\quad$ Tidak & 66 & 47,5 \\
\hline Faktor kebutuhan (need) & & \\
Tidak butuh & 42 & 30,2 \\
$\quad$ Butuh & 97 & 69,8 \\
\hline Perilaku pemanfaatan pelayanan gizi & & 66,2 \\
Tidak & 92 & 33,8 \\
Ya & 47 & \\
\hline
\end{tabular}

Hasil penelitian mendapatkan rata-rata umur ibu hamil diatas 20 tahun sebanyak $89,2 \%$ dengan paritas primipara sebanyak $66,9 \%$. Umumnya ibu hamil tidak bekerja sebanyak $71,9 \%$ dengan latar belakang pendidikan rendah sebanyak $50,4 \%$. Pengetahuan ibu hamil masih tidak baik sebanyak 54\% dengan sikap tidak baik sebanyak 66,9\%. Pendapatan keluarga dibawah UMR (Rp.3.827.000) sebanyak 54,7\%. Ibu hamil menyatakan jarak rumah yang dekat dengan tempat pelayanan kesehatan gizi sebanyak 50,4\%. Dukungan suami sebanyak 52,5\%. Ibu hamil menyatakan butuh akan pelayanan gizi sebanyak $69,8 \%$. Secara keseluruhan ibu hamil tidak memanfaatkan pelayanan gizi sebanyak 66,2\% (tabel 1).

Tabel. 2

Perilaku Pemanfaatan Pelayanan Klinik Gizi

\begin{tabular}{|c|c|c|c|c|c|c|}
\hline \multirow{3}{*}{ Variabel } & \multicolumn{4}{|c|}{$\begin{array}{l}\text { Perilaku pemanfaatan pelayanan gizi } \\
\text { oleh ibu hamil dengan risiko KEK }\end{array}$} & \multirow{3}{*}{ Total } & \multirow{3}{*}{$\mathrm{P}$ value } \\
\hline & \multicolumn{2}{|c|}{ Tidak } & \multicolumn{2}{|c|}{$\mathrm{Ya}$} & & \\
\hline & $\mathrm{n}$ & $\%$ & $\mathrm{n}$ & $\%$ & & \\
\hline \multicolumn{7}{|l|}{ Umur } \\
\hline$\leq 20$ tahun & 10 & 66,7 & 5 & 33,3 & 15 & 1,000 \\
\hline$>20$ tahun & 82 & 66,1 & 42 & 33,9 & 124 & \\
\hline \multicolumn{7}{|l|}{ Paritas } \\
\hline Primipara & 67 & 72,0 & 26 & 28,0 & 93 & 0,114 \\
\hline Multipara & 23 & 54,8 & 19 & 45,2 & 42 & \\
\hline Grandmultipara & 2 & 50,0 & 2 & 50,0 & 4 & \\
\hline \multicolumn{7}{|l|}{ Pekerjaan } \\
\hline Tidak bekerja & 64 & 64,0 & 36 & 36,0 & 100 & 0,501 \\
\hline Bekerja & 28 & 71,8 & 11 & 28,2 & 39 & \\
\hline \multicolumn{7}{|l|}{ Pendidikan } \\
\hline Rendah & 49 & 70,0 & 21 & 30,0 & 70 & 0,437 \\
\hline Tinggi & 43 & 62,3 & 26 & 37,7 & 69 & \\
\hline \multicolumn{7}{|l|}{ Pengetahuan } \\
\hline Tidak baik & 62 & 82,7 & 13 & 17,3 & 75 & 0,000 \\
\hline Baik & 30 & 46,9 & 34 & 53,1 & 64 & \\
\hline
\end{tabular}




\begin{tabular}{lcccccc}
\hline Sikap & 66 & 71,0 & 27 & 29,0 & 93 & 0,133 \\
Tidak baik & 26 & 56,6 & 20 & 43,5 & 46 & \\
$\begin{array}{l}\text { Baik } \\
\text { Pendapatan keluarga }\end{array}$ & & & & & & \\
<UMR (Rp.3.827.000) & 60 & 78,9 & 16 & 21,1 & 76 & 0,001 \\
>UMR (Rp.3.827.000 & 32 & 50,8 & 49,2 & 49,2 & 63 & \\
\hline Jarak pelayanan kesehatan & & & & & & \\
Jauh ( $\geq 5 \mathrm{~km})$ & 49 & 71,0 & 20 & 29,0 & 69 & 0,310 \\
Dekat (<5 km) & 43 & 61,4 & 27 & 38,6 & 70 & \\
\hline Dukungan suami & & & & & & \\
Tidak & 63 & 86,3 & 10 & 13,7 & 73 & 0,000 \\
Ya & 29 & 43,9 & 37 & 56,1 & 66 & \\
\hline Faktor kebutuhan (need) & & & & & & \\
Tidak butuh & 38 & 90,5 & 4 & 9,5 & 42 & 0,000 \\
Butuh & 54 & 55,7 & 43 & 44,3 & 97 & \\
\hline
\end{tabular}

Analisis bivariat menunjukkan bahwa tidak ada hubungan antara umur ( $\mathrm{p}$ value $=$ $1,000)$, paritas $(\mathrm{p}$ value $=0,114)$, pekerjaan $(\mathrm{p}$ value $=0,501)$, pendidikan $(\mathrm{p}$ value $=$ $0,437)$, sikap ( $\mathrm{p}$ value $=0,133)$, jarak pelayanan kesehatan $(\mathrm{p}$ value $=0,310)$ terhadap perilaku pemanfaatan pelayanan gizi oleh ibu hamil dengan risiko KEK di Klinik Gizi Puskesmas Kasemen Kota Serang.

Ada hubungan antara pengetahuan ( $\mathrm{p}$ value $=0,000)$, pendapatan keluarga $(\mathrm{p}$ value $=0,001)$, dukungan suami $(\mathrm{p}$ value $=0,000)$, dan faktor kebutuhan (need) $(\mathrm{p}$ value $=0,000)$ terhadap perilaku pemanfaatan pelayanan gizi oleh ibu hamil dengan risiko KEK di Klinik Gizi Puskesmas Kasemen Kota Serang. Dapat dilihat pada tabel 2.

Tabel. 3

Analisis Multivariat Determinan Perilaku Pemanfaatan Pelayanan Gizi oleh Ibu Hamil dengan Risiko KEK

\begin{tabular}{lccccc}
\hline Variabel & $\mathrm{B}$ & $\mathrm{SE}$ & Nilai $_{\mathrm{p}}$ & OR & 95\%CI \\
\hline Dukungan suami & 1,843 & 0,446 & 0,000 & 6,314 & $2,633-15,138$ \\
Faktor kebutuhan (need) & 1,652 & 0,600 & 0,006 & 5,217 & $1,608-16,926$ \\
Pendapatan keluarga & 0,910 & 0,434 & 0,036 & 2,483 & $1,061-5,814$ \\
Konstanta & $-3,445$ & 0,637 & 0,000 & 0,032 & \\
\hline
\end{tabular}

Analisis multivariat menunjukkan bahwa faktor dominan perilaku pemanfaatan pelayanan gizi oleh ibu hamil dengan risiko KEK di Klinik Gizi Puskesmas Kasemen Kota Serang tahun 2019 adalah dukungan suami (OR=6,3; 95\% CI: 2,633-15,138), faktor kebutuhan (need) $(\mathrm{OR}=5,2 ; 95 \% \mathrm{CI}$ : 1,608-16,926) dan pendapatan keluarga $(\mathrm{OR}=2,5 ; 95 \%$ CI: 1,061-5,814) . Dapat dilihat pada tabel 3.

\section{PEMBAHASAN}

Hasil penelitian ini menunjukkan bahwa dari 139 ibu hamil yang terlibat sebagai responden penelitian, terdapat sebanyak 92 ibu hamil $(66,2 \%)$ tidak memanfaatkan pelayanan gizi. Ibu hamil membutuhkan pelayanan kesehatan dan informasi tentang masalah kesehatan dan gizi yang dihadapinya. Faktor manusia dalam hal ini memegang peranan sangat penting dalam penciptaan perilaku pemanfaatan pelayanan kesehatan. Pemanfaatan pelayanan kesehatan merupakan hasil dari proses pencarian pelayanan kesehatan oleh ibu hamil dan menghasilkan suatu model perilaku pemanfaatan pelayanan kesehatan (behavioral model of health services utilization) (Tolera et al., 2020). 
Jumlah ibu yang tidak melakukan pemanfaatan pelayanan kesehatan ini lebih rendah dari penelitian sebelumnya yang yang dilakukan oleh Nuepane et al., (2020) di Nepal yang menunjukkan bahwa dua dari tiga (69,8\%) dengan kelahiran terakhir mengakses setidaknya empat kunjungan ANC. Perilaku pemanfaatan pelayanan kesehatan ini secara signifikan dipengaruhi oleh dipengaruhi oleh usia, tingkat pendidikan ibu dan tingkat pendidikan suami, dan keterpaparan informasi pada ibu hamil ((Neupane et al., 2020). Jumlah kunjungan ini berisiko semakin menurun selama masa pandemi Covid-19 terutama dengan diberlakukannya satndar protokol kesehatan dalam pelayanan kesehatan maternal selama masa pandemic-Covid-19. Tadesse (2020) melaporkan hasil penelitiannya di wilayah Northeast Ethiopia tahun 2020 bahwa kurang dari sepertiga ibu hamil $(29,3 \%)$ yang melakukan kunjungan ANC secara lengkap selama pandemic Covid-19.

Perilaku pemanfaatan pelayanan kesehatan gizi oleh ibu hamil dengan risiko KEK disebabkan oleh faktor dukungan suami. Hasil penelitian menunjukkan bahwa faktor dominan perilaku pemanfaatan pelayanan gizi oleh ibu hamil dengan risiko KEK di Klinik Gizi Puskesmas Kasemen Kota Serang tahun 2019 adalah dukungan suami $(\mathrm{OR}=6,3 ; 95 \% \mathrm{CI}: 2,633-15,138)$. Artinya bahwa ibu hamil yang mendapatkan dukungan suami berpeluang 6,3 kali lebih besar memanfaatkan pelayanan gizi dibandingkan dengan ibu hamil yang tidak mendapatkan dukungan suami. Sejalan dengan penelitian sebelumnya yang dilakukan oleh Yusmaharani (2018) mengenai pentingnya dukungan suami dengan pemanfaatan pelayanan kesehatan gizi oleh ibu dengan risiko KEK dengan ( $\mathrm{p}$ value $=0,001)$ dan nilai $(\mathrm{OR}=11,7 ; 95 \% \mathrm{CI}$ : 4,411-31,117).

Dukungan suami mempengaruhi dalam keikutsertaan kelas ibu hamil di Puskesmas. Peran suami dalam perilaku pemanfaatan pelayanan gizi sangat penting, suami sebagai orang terdekat dengan ibu hamil sebagai motivator untuk memeriksakan kehamilannya serta mendukung ibu hamil baik secara moril maupun materil, sehingga ibu dapat melalui kehamilannya dengan baik. Penelitian yang dilakukan di Puskesmas Sangurara Kota Palu tahun 2018 menunjukkan bahwa terdapat hubungan yang signifikan antara dukungan suami dengan pemanfaatan pelayanan kesehatan (antenatal care) pada ibu hamil (Lisnawati et al., 2019).

Faktor kebutuhan (need), terkait penyakit yang dideritanya merupakan keputusan pertama yang menentukan tingkah laku seseorang untuk meminta pengobatan atau tidak. Hasil penelitian ini menemukan ada hubungan antara faktor kebutuhan dengan perilaku pemanfaatan pelayanan gizi ( $\mathrm{p}$ value $=0,006 ;<0,05)$ dengan nilai $(\mathrm{OR}=5,2 ; 95 \% \mathrm{CI}$ : 1,608-16,926). Artinya bahwa faktor kebutuhan dalam hal ini ibu merasa takut terhadap penyakit yag dideritanya berpeluang 5,2 kali lebih besar memanfaatkan pelayanan gizi dibandingkan dengan ibu hamil yang tidak merasa takut terhadap penyakit yang dideritanya. Faktor need characteristics diantaranya, penilaian individu (perceived need) yaitu penilaian kondisi kesehatan yang dirasakan oleh individu, besarnya ketakutan terhadap penyakit dan hebatnya rasa sakit yang diderita merupakan salah satu determinan yang menentukan perilaku kesehatan ibu hamil. Selanjutnya outcome dari perilaku kesehatan ini yaitu pemanfaatan pelayanan kesehatan pada periode kehamilan ini akan mempengaruhi outcome kehamilan terutama kesehatan ibu dan bayi yang dilahirkan (Tolera et al., 2020; Neupane et al., 2020).

Penelitian yang dilakukan di wilayah Ghana melaporkan bahwa terdapat beberapa penyebab atau hambatan bagi ibu sehingga tidak memanfaatkan pelayanan kesehatan secara optimal terutama pelayanan gizi meskipun ibu memiliki kebutuhan (needs factor) terhadap pelayanan tersebut, yaitu rendahnya keterjangkauan fasilitas kesehatan tersebut 
(Konlan et al., 2020). Persepsi terhadap ibu hamil dengan risiko KEK dan cara ibu menaggapi penyakit akan menentukan apakah memanfaatkan pelayanan kesehatan gizi atau tidak. Jadi secara umum dapat dikatakan bahwa faktor kebutuhan (need) merupakan faktor penentu bagi individu dalam memanfaatkan pelayanan kesehatan gizi di Klinik Gizi Puskesmas Kasemen Kota Serang.

Pendapatan keluarga memiliki peran penting dalam proses pengambilan keputusan mencari pelayanan kesehatan. Hasil penelitian menemukan bahwa ada hubungan antara pendapatan keluarga dengan perilaku pemanfaatan pelayanan gizi dengan nilai $(\mathrm{OR}=2,5$; 95\% CI: 1,061-5,814). Artinya bahwa ibu hamil dengan pendapatan keluarga diatas UMR berpeluang 2,5 kali lebih besar memanfaatkan pelayanan gizi dibandingkan dengan ibu hamil dengan pendapatan keluarga dibawah UMR. Hal ini sejalan dengan penelitian yang dilakukan oleh (Rabbaniyah \& Nadjib, 2019), pendapatan kepala rumah tangga berpengaruh secara signifikan terhadap pemanfaatan fasilitas kesehatan dengan koefisien logit 0,301 dan provit 0,093 ( $\mathrm{p}$ value $=0,001$ ).

Dapat dikatakan bahwa semakin tinggi pendapatan kepala rumah tangga, maka semakin tinggi pula kemungkinan untuk memanfaatkan fasilitas kesehatan untuk berobat jalan. Penelitian lain menyatakan faktor sosial ekonomi yaitu pendapatan, pekerjaan, dan kepemilikan jaminan kesehatan mempengaruhi dalam pemanfaatan fasilitas kesehatan (Farisni, 2017; Yoga \& Prakoso, 2018). Dengan subsidi yang diberikan oleh Pemerintah kepada masyarakat secara gratis namun hal tersebut bagi masyarakat dengan golongan yang berpendapatan rendah tetap membutuhkan biaya yang cukup dalam hal lainnya, seperti misalnya dibutuhkan biaya transportasi ke sarana pelayanan kesehatan, ataupun biaya kebutuhan lain saat menjalani perawatan di Puskesmas atau Rumah sakit.

\section{SIMPULAN}

Kesimpulan dari penelitian ini adalah faktor dominan perilaku pemanfaatan pelayanan gizi oleh ibu hamil dengan risiko KEK di Puskesmas Kasemen Kota Serang tahun 2019 adalah dukungan keluarga, faktor kebutuhan (need) dan pendapatan keluarga.

\section{SARAN}

Puskesmas

Dengan adanya penelitian ini Puskesmas diharapkan dapat meningkatkan kualitas pelayanan gizi bagi ibu hamil. Memberikan penyuluhan mengenai pentingnya untuk memanfaatkan fasilitas pelayanan gizi bagi ibu hamil. Unit pelayanan kesehatan perlu melakukan door to door ke daerah yang sulit dijangkau agar pelayanan gizi tersebut dapat diberikan.

\section{Masyarakat/Keluarga}

Dengan adanya penelitian ini diharapkan keterlibatan keluarga terutama suami mampu memberikan motivasi bagi ibu hamil untuk memanfaatkan fasilitas pelayanan gizi bagi ibu hamil. Meningkatkan pengetahuan mengenai pelayanan gizi ibu hamil dengan cara mengikuti kegiatan dari Puskesmas maupun media sosial dan internet.

Peneliti Selanjutnya

Penelitian ini dapat menjadi referensi untuk penelitian selanjutnya peneliti menggunakan metode kualitatif sehingga dapat menggali informasi lebih dalam 
mengenai faktor pemanfaatan pelayanan gizi. Penelitian berikutnya dapat diangkat seperti faktor pemanfaatan pelayanan gizi pada balita dengan status stunting.

\section{DAFTAR PUSTAKA}

Akowuah, J. A., Agyei-Baffour, P., \& Awunyo-Vitor, D. (2018). Determinants of Antenatal Healthcare Utilisation by Pregnant Women in Third Trimester in PeriUrban Ghana. Journal of Tropical Medicine, 2018(2000). DOI: $10.1155 / 2018 / 1673517$

Ali, S. A., Dero, A. A., Ali, S. A., \& Ali, G. B. (2018). Factors Affecting the Utilization of Antenatal Care among Pregnant Women: A Literature Review. Journal of Pregnancy and Neonatal Medicine, 02(02), 41-45. doi: 10.35841/neonatalmedicine.2.2.41-45

Ariani, A., Lestari S., \& Hayati, N. (2020). Pengaruh Kelas Pojok Gizi dalam Pemberian Makanan Bayi \& Anak (PMBA) terhadap Status Gizi untuk Pencegahan Stunting. Jurnal Nursing Update, 11(3), 1-8. https://stikes-nhm.ejournal.id/NU/index

Farisni, T. N. (2017). Determinan Pemanfaatan Fasilitas Kesehatan oleh Ibu Hamil. Prosiding Seminar Nasional IKAKESMADA, 243-251. http://eprints.uad.ac.id/5418/

Griffiths, L. J., Johnson, R. D., Broadhurst, K., Bedston, S., Cusworth, L., Ford, D. V., \& John, A. (2020). Maternal Health, Pregnancy and Birth Outcomes for Women Involved in Care Proceedings in Wales: A Linked Data Study. BMC Pregnancy and Childbirth, 20(1), 1-13. doi: 10.1186/s12884-020-03370-4

Kemenkes RI. (2018). Laporan Kinerja Dinas Kesehatan Tahun 2018," Laporan Kinerja Dinas Kesehatan Tahun 2018, hal. 2-245. http://ppid.kemkes.go.id/uploads/img_60e3bf9067064.pdf

Kemenkes RI. (2019). Laporan Nasional Riskesdas 2018, Badan Penelitian dan Pengembangan Kesehatan. Jakarta: Badan Penelitian dan Pengembangan Kesehatan. https://www.litbang.kemkes.go.id/laporan-riset-kesehatan-dasarriskesdas/

Kemenkes Rl. (2019). Laporan Provinsi Banten Riskesdas 2018, Badan Penelitian dan Pengembangan Kesehatan. Jakarta: Badan Penelitian dan Pengembangan Kesehatan

Konlan, K. D., Saah, J. A., Amoah, R. M., Doat, A. R., Mohammed, I., Abdulai, J. A., \& Konlan, K. D. (2020). Factors Influencing the Utilization of Focused Antenatal Care Services During Pregnancy, A Study Among Postnatal Women in a Tertiary Healthcare Facility, Ghana. Nursing Open, 7(6), 1822-1832. DOI: 10.1002/nop2.569

Lisnawati, L., Sumiaty, S., \& Fadliah, U. (2019). Husband Support and the Activity of Health Officers to Antenatal Care (ANC) Visits of Pregnant Women. Urban Health, 2(1), 167-176. http://journal.poltekkesmks.ac.id/ojs2/index.php/Prosiding/article/view/1195

Neupane, B., Rijal, S., Srijana, G. C., \& Basnet, T. B. (2020). Andersen's Model on Determining the Factors Associated with Antenatal Care Services in Nepal: An Evidence-Based Analysis of Nepal Demographic and Health Survey 2016. BMC Pregnancy and Childbirth. BMC Pregnancy and Childbirth, 20(1), 1-11. DOI: 10.1186/s12884-020-02976-y 
Padila, P., Amin, M., \& Rizki, R. (2018). Pengalaman Ibu dalam Merawat Bayi Preterm yang Pernah dirawat di Ruang Neonatus Intensive Care Unit Kota Bengkulu. Jurnal Keperawatan Silampari, 1(2), 1-16. https://doi.org/10.31539/jks.v1i2.82

Pemerintah Kota Serang. (2020). Laporan Akhir Profil Gender dan Anak Kota Serang Tahun 2020.

Serang. https://bappeda.serangkota.go.id/content/uploads/pofil_gender_dan_anak_kota_se rang_compressed.pdf

Permatasari, T. A. E., Sartika, R. A. D., Achadi, E. L., Purwono, U., Irawati, A., Ocviyanti, D., \& Martha, E(2018). Exclusive Breastfeeding Intention among Pregnant Women. Kesmas: National Public Health Journal, 12(3), 134-141. Doi: 10.21109/kesmas.v12i3.1446

Permatasari, T. A. E., Widjajanti, W., Sunarto, A., Andriyani, A., \& Ramadhan, A. I. (2020). Factors Related to the Granting of Colostrum in Newborn Baby with Caesarean Section in Hospital Government at Banten, Indonesia. Food Science and Technology (United States), 8(3), 61-72. doi: 10.13189/fst.2020.080303

Permatasari, T. A. E., Rizqiya, F., Kusumaningati, W., Suryaalamsyah, I. I., \& Hermiwahyoeni, Z. (2021). The Effect of Nutrition and Reproductive Health Education of Pregnant Women in Indonesia Using Quasi Experimental Study. BMC Pregnancy and Childbirth, 21(180), 1-15. doi: 10.1186/s12884-021-03676-X

Permatasari, T. A. E. dan Sudiartini, N. W. (2020). Do Health Workers Play a Role in Exclusive Breastfeeding among Working Mothers in Industrial Area?. Journal of Nutritional Science and Vitaminology, 66, S94-S98. Doi: 10.3177/jnsv.66.S94

Puskesmas Kasemen. (2019). Profil Kesehatan Kasemen 2018. Serang. https://serangkota.bps.go.id/publication/2018/09/26/dba88f3a071d082a765dab54/ kecamatan-kasemen-dalam-angka-2018.html

Rabbaniyah, F., \& Nadjib, M. (2019). Analisis Sosial Ekonomi dalam Pemanfaatan Fasilitas Kesehatan untuk Berobat Jalan di Provinsi Jawa Barat : Analisis Data Susenas Tahun 2017. Media Kesehatan Masyarakat Indonesia, 15(1), 73-80. DOI: 10.30597/mkmi.v15i1.5888

Tadesse, E. (2020). Antenatal Care Service Utilization of Pregnant Women Attending Antenatal Care in Public Hospitals During the Covid-19 Pandemic Period. International Journal of Women's Health, 12, 1181-1188. doi: 10.2147/IJWH.S287534

Tolera, H., Gebre-Egziabher, T., \& Kloos, H. (2020). Using Andersen's Behavioral Model of Health Care Utilization in a Decentralized Program to Examine the Use of Antenatal Care in Rural Western Ethiopia. PLoS ONE, 15(1), 1-18. DOI: 10.1371/journal.pone.0228282

Yoga, A. D., \& Prakoso, B. S. E. (2018). Pemanfaatan Fasilitas Kesehatan oleh Masyarakat Kabupaten Kulon Progo (Kasus: Kecamatan Wates dan Kecamatan Kalibawang). Jurnal Bumi Indonesia, 7(3), 1-12. https://media.neliti.com/media/publications/260742-none-2382119c.pdf

Yusmaharani, Y. (2018). Hubungan Dukungan Suami dengan Pemanfaatan Kelas Ibu Hamil di Wilayah Kerja Puskesmas Harapan Raya Pekanbaru. Kesmars, 1(1), 1-5. DOI: 10.31539/kesmars.v1i1.149 